Jayapangus Press

Jurnal Penelitian Agama Hindu

Terakreditasi Peringkat 2
Volume 5 Nomor 3 (2021)

ISSN : 2579-9843 (Media Online)

http://jayapanguspress.penerbit.org/index.php/JPAH

\title{
HARMONISASI PAKSA SIWA DAN PAKSA BUDHA DI BALI (PERSPEKTIF TEOLOGI KONTEKSTUAL)
}

\author{
I Nyoman Kiriana \\ Universitas Hindu Negeri I Gusti Bagus Sugriwa Denpasar \\ kiriana@uhnsugriwa.ac.id
}

\begin{abstract}
This article is the result of qualitative research using hybridity theory and the concept of the Siwa-Buddha theology (I Gusti Bagus Sugriwa). Hinduism and Buddhism are one of the religions found in Indonesia and initially developed and was born in India. Even so, the existence of these two religions is disharmonious in the land of their birth. The problem studied is the factors that cause Siwa-Buddha to coexist harmoniously in Bali. The method used in this research is a qualitative method with an interfretative paradigm. The object of his study is the harmonization of Siwa and Buddha in Bali. The result and discussion is that the factors that cause Siwa-Buddha Coexistence in Bali include theological, philosophical, historical, psychological and sociological factors. (1) The telogical factor of Siwa teachings is manifested by the symbol of Ongkara, while in Budha it is called Hrih. (2) The philosophical factor of Siwa-Buddha harmony in Bali in the concept of deliverance in Hindu religious beliefs will lead to the realm of Sünya and Nirvana in Budha beliefs. (3) Historical factors in the area of origin Siwa-Buddha experienced great conflict and became a dark historical record, but in Indonesia on the contrary Siwa-Buddha lived in harmony and hamonis. (4) The psychological factor of tantric Siwa-Buddha teachings, the human body as a miniature universe it becomes the center of a quest to the One through the use of Aksara, Mantra, Yantra, Mudra, and Yoga. (5) The sociological factors of the Balinese Hindu community are familiar with that Siwa-Budha are indeed one and One. Bhatara Siwa-Buddha withtraits Ardhanareswari in Bali is known as Hyang Tunggal. The existence of Śiwa-Buddha in Bali, which is a meeting between two beliefs and can live side by side and in harmony in Bali.
\end{abstract}

Keywords: Harmonization; Paksa Siwa-Buddha

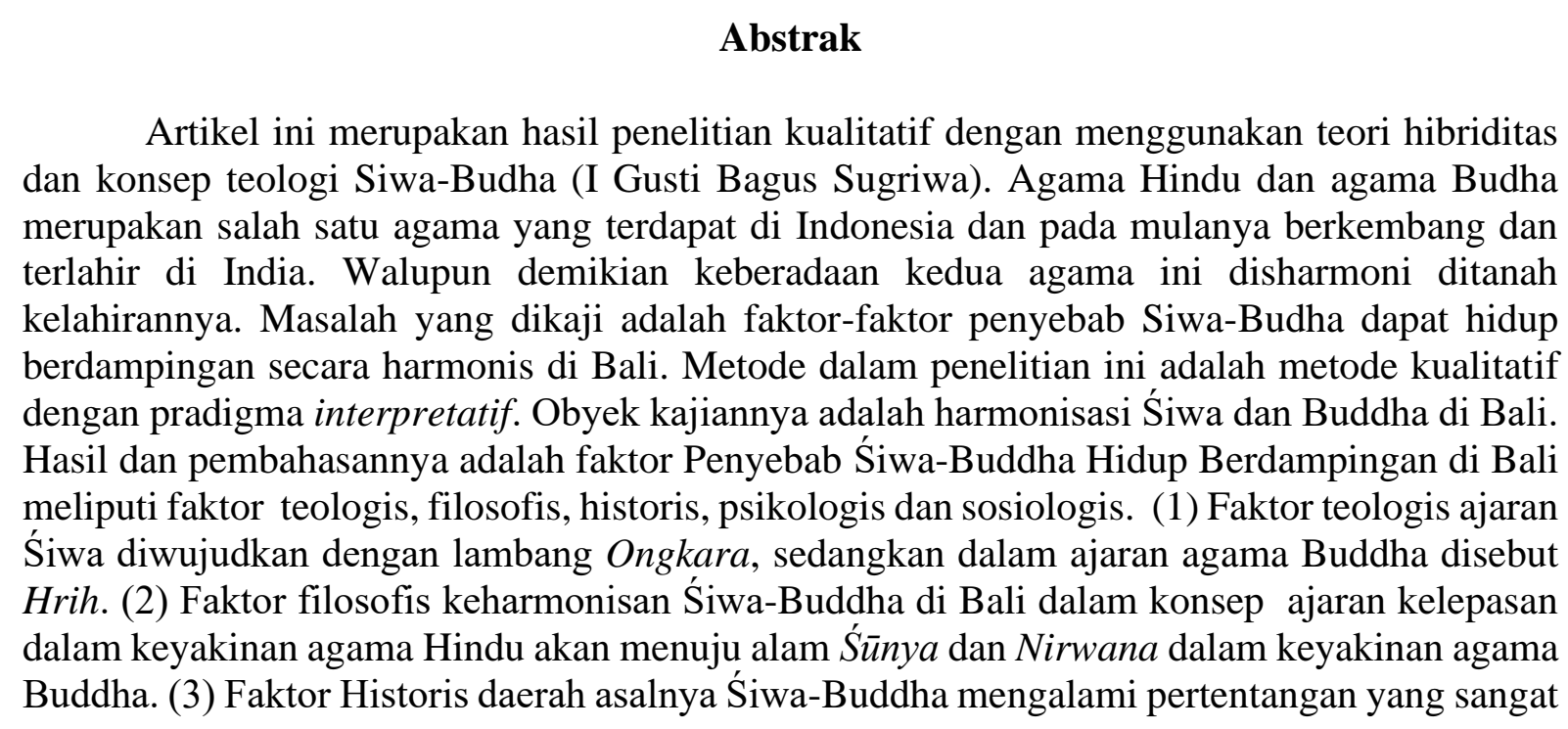


hebat dan menjadi catatan sejarah yang kelam, akan tetapi di Indonesia malah sebaliknya ŚiwaBuddha hidup rukun dan harmonis. (4) Faktor psikologis ajaran Śiwa-Buddha yang tantris, tubuh manusia sebagai miniatur alam semesta menjadi pusat pencarian menuju yang Tunggal melalui penggunaan Aksara, Mantra, Yantra, Mudra, dan Yoga. (5) Faktor sosiologis masyarakat Hindu Bali mengakrabi bahwa Śiwa dan Buddha itu memang satu dan Esa. Bhatara Śiwa-Buddha dengan sifat-sifat Ardhanareswari di Bali di kenal sebagai Hyang Tunggal. Keberadaan Śiwa-Buddha di Bali yang merupakan pertemuan antara dua keyakinan dan dapat hidup berdampingan dan harmonis di Bali.

\section{Kata Kunci : Harmonisasi; Paksa Siwa-Budha}

\section{Pendahuluan}

Indonesia merupakan salah satu negara yang multikultural. Di Indonesia terdapat beberapa agama dan juga suku bangsa. Agama Hindu dan Buddha merupakan agama yang terdapat di Indonesia, dimana kedua agama ini pada mulanya lahir dan berkembang di negara India. Berdasarkan fenomena yang terjadi bahwa di India agama Hindu dan Budha tidak dapat hidup damai, tetapi saling bertentangan sehingga menimbulkan berbagai selisih paham. Hal ini dapat terlihat pada masa pemerintahan kerajaan Magadha, dimana kaum Brahmana bangkit melakukan sebuah perlawanan pada pemerintahan yang beragama Buddha. Pushyamitra kemudian menjadi salah satu pelopor yang memusnahkan pengaruh agama Buddha di India. Hal ini juga diperparah oleh gerakan yang dilakukan oleh Saýkaracarya yang berhasil memenangkan perdebatan dengan bhiksu-bhiksu Buddha, sehingga mengakibatkan para pengikut Buddha sebagian besar kembali ke Hindu.

Sebaliknya, agama Hindu dan Budha dapat hidup berdampingan di Indonesia khususnya di Bali secara damai dan saling menghargai sebagai wujud dari toleransi beragama. Terdapat beberapa kesamaan antara ajaran Siwa dan Budha, dimana ajaran Budha itu sendiri merupakan inti sari dari ajaran agama Hindu. Jika diibaratkan sebuah telur, agama Siwa (Hindu) merupakan putih telur, sedangkan Budha merupakan kuning telur. Sinkretisme SiwaBudha merupakan kearifan lokal yang terdapat di Bali yang harus terus dilestarikan sebagai wujud dari moderasi beragama. Dimana hasil dari interaksi tersebut menciptakan kedamaian.

Ajaran Siwa-Budha kemudian menjadi sebuah kepercayaan yang tumbuh dalam kehidupan beragama di Bali dan sudah diwariskan secara turun menurun hingga saat ini. Hal ini dapat kita lihat pada praktek ritual keagamaan Hindu, khususnya di Bali yang dikenal dengan konsep Śiwa Buddha. Konsep Śiwa Buddha di Bali terlihat pada pemujaan yang dilakukan di Pura Besakih, dapat dilihat dengan adanya istilah pendeta (padanda) yang sering dijuluki padanda Śiwa dan padanda Budha. Agama Buddha di Bali dapat Bersatu dan berdampingan dengan agama Śiwa sehingga dapat hidup dengan rukun dan harmoni di Bali.

Penelitian tentang Śiwa-Buddha sudah banyak dilakukan, namun nampaknya ada beberapa persoalan yang belum tuntas dikupas terkait dengan faktor penyebab paksa SiwaBudha hidup berdampingan dan harmonis di Bali. Penelitian-penelitian yang dilakukan terkait dengan keberadaan Siwa dan Buddha, hampir semuanya meneliti tentang Siwa dan Buddha dalam konteks agama Hindu dan agama Buddha. Namun dalam penelitian ini, Śiwa-Buddha yang dimaksud adalah (agama Śiwa-Buddha) yang kemudian menjadi Agama Hindu di Bali.

\section{Metode}

Artikel ini merupakan tema kecil dari penelitian yang berjudul "Hibriditas Śiwa dan Buddha dalam Upacara tawur Kasanga di Bancingah Agung Pura Besakih" (Kiriana, 2021). Pendekatan yang digunakan adalah penelitian kualitatif dengan paradigma interpretatif. Obyek kajiannya adalah harmonisasi Śiwa dan Buddha di Bali. Penelitian lapangan dengan jenis penelitian yang digunakan adalah kualitatif dengan paradigma interpretatif. Pendekatan dalam 
penelitian ini adalah pendekatan fenomenologi yang berusaha menggali tentang paksa siwabudha di Bali. Para informan tersebut dipilih berdasarkan pertimbangan bahwa informan dimaksud memiliki pengetahuan dan pengalaman yang berkaitan dengan Śiwa-Buddha di Bali. Peneliti meyakini bahwa para informan tersebut memenuhi syarat dan dapat dipertanggungjawabkan informasi dan atau pandangannya, mengingat yang bersangkutan adalah tokoh agama dan pemuka masyarakat seperti para Padanda Śiwa dan Padanda Buddha.

\section{Hasil dan Pembahasan}

Kemajemukan kehidupan beragama yang terdapat di Bali, menimbulkan toleransi beragama yang sangat tinggi sebagai wujud dari moderasi beragama. Kesadaran masyarakat Bali akan keheterogenan sebagai wujud dari pengimplementasian ajaran Tat Twam Asi dan Tri Hita Karana dalam kehidupan masyarakat. Kemajemukkan itu dalam kehidupan bermasyarakat dipandang sebagai suatu nilai yang positif. Dimana dalam kehidupan beragama, setiap umat bergama memiliki cara yang berbeda-beda tetapi tujuannya adalah sama. Tidak ada agama yang mengajarkan keburukan karena setiap agama sejatinya senantiasa mengajarkan kebaikan untuk umat penganutnya. Kemajemukan dalam kehidupan beragama di Bali sebagai suatu alat untuk memupuk toleransi umat beragama. Dimana sejatinya setiap umat beragama sebagai makhluk individu dan makhluk sosial saling membutuhkan dan melengkapi satu sama lainnya.

Realisasi dari masing-masing ajaran agama dalam kehidupan masyarakat yang majemuk sesungguhnya memiliki esensi untuk dapat mewujudkan keharmonisan antar umat manusia. Etika dasar terhadap manusia dan kemanusiaan adalah setiap manusia harus diperlakukan secara manusiawi (Suhardana, 2008). Demikan pula halnya dengan keberadaan Śiwa-Buddha di Bali yang merupakan pertemuan antara dua keyakinan dan dapat hidup berdampingan di Bali. Śiwa-Buddha di Bali dapat hidup berdampingan dalam suasana yang harmonis dan humanis yang disebabkan oleh beberapa faktor sebagai berikut :

\section{Faktor Teologis}

Secara teologis, keesaan Śiwa-Buddha disebut dengan Sanghyang Tunggal. Dalam ajaran Śiwa yang kemudian diwujudkan dengan menggunakan simbol Ongkara. Sedangkan dalam ajaran Buddha disimbolkan dengan Hrih. Dimana kemudian muncul sebuah konsep yang disebut dengan purusa dan pradhana. Kedua konsep ini kemudian dikenal dengan istilah Rwabhineda. Goris (1974) meneliti isi bhuwanakosa, bhuwanasangksepa, tattwajñàna dan beberapa pùja (doa-doa pujian dalam bahasa Sanskerta kepulauan yang dilafalkan pada waktu upacara agama Hindu) untuk disertasinya: Bijdragen tot de Kennis van de Oudjavaansche Theologie. Goris peneliti pertama yang memperkenalkan teologi Hindu Jawa Kuno dan Hindu Bali yang tergolong ke dalam paksa Saiwasiddhànta.

Karya Goris dikembangkan oleh Zieseniss yang menulis Studien zur Geschichte Des Çivaismus (Goris, 1984). Karyanya ini menguraikan evolusi ajaran Saiwasiddhànta di Jawa dan Bali yang di sana-sini dikaitkan dengan sumber India. Karya Zieseniss yang lain yang berjudul Studien zur Geschichte Des Çivaismus, Die Saiva Systematik des Våhaspatitattva khusus menguraikan Vrhaspatitattva dengan terjemahannya dalam bahasa Jerman. Haryati Soebadio menyunting dan menerjemahkan Jñànasiddhànta dengan amat cermat. Hal ini memberikan inspirasi lanjut menyunting dan menerjemahkan teks-teks sejenis. Naskah-naskah sejenis yang memuat ajaran-ajaran tattwa telah pula disunting dan diterjemahkan ke dalam bahasa Inggris dalam serial Sata-Pitaka Indonesian Lituratures seperti Vrhaspatitattwa, Tattwajñàna, Mahàjñàna.

Teologi Hindu adalah ajaran ketuhanan yang berdasarkan kitab suci Veda sebagai kitab suci agama Hindu (Girinata, 2020). Veda sebagai pengetahuan yang mengandung segala macam ilmu pengetahuan, maka hal tersebut mengandung makna juga bahwa Veda bukanlah hanya untuk umat Hindu saja, Veda adalah untuk seluruh umat manusia. Siapapun dapat 
membuktikan kebenaran Veda dan tidak harus dibuktikan oleh orang-orang Hindu. Brahma Vidya sebagai pengetahuan tentang Tuhan tidak saja dimaknai sebagai ilmu tentang Tuhan untuk mengetahui Tuhan secara yang abolutisme, tetapi lebih kepada cara menghayati Tuhan atau Ida Sang Hyang Widhi Wasa. Dengan demikian, pada prinsipnya tidaklah banyak ada perbedaan antara doktrin Śiwa dan Buddha. Keduanya menekankan pada prinsip dari dwi tunggal (duality in non duality) (Mantra, I.B., 2002).

Terdapat beberapa kemiripan antara penjelasan Asta Murti Śiwa dengan kemanunggalan Śiwa-Buddha. Hal ini dikarenakan dalam proses penyatuan Śiwatatwa dengan Bhudhatattwa, tampak adanya penjelasan tentang Asta Murti Śiwa (Pretiwimurtiyajamanamurti). Begitu pula sebaliknya dalm proses penjelasan Asta Murti Śiwa tentu tidak bisa lepas dari uraian proses penyatuan Śiwa tattwa dengan Bhudatatwa, karena berasal dari sumber yang sama. Terkait dengan fungsi Padanda Śiwa Buddha dalam rangkaian upacara besar atau setingkat tawur, pendeta Śiwa memuja Ayun Widhi memanisfestasikan akasa, purusa, memuja Prajnamatra yaitu Yajamanamurti pada saat itu beliu bergelar Hotri, Pasupati, Daksita Brahamana atau Brahman.

Kedatangan paham Siwa ke Bali diawali dengan datangnya Rsi Markandeya sekitar abad ke-8. Setelah itu, ajaran Siwa diteruskan oleh Mpu Sangkul Putih yang memberikan unsur lain dan warna dalam paham Siwa Siddhanta, dan selanjutnya datanglah Mpu Kuturan ke Bali untuk mempersatukan sekte di Bali. Pada saat beliau sampai di Bali, sangat banyak bermunculan sekte-sekte atau paksa. Pada akhirnya Mpu Kuturan kembali menyatukan sekte tersebut dalam satu kesatuan mazhab Siwa Siddhanta, dan menempatkan Tuhan Siwa sebagai titik sentral, kendatipun Deva lainnya, baik lokal dan yang lainnya dipuja. Selanjutnya datanglah Mpu Manik Angkeran dan Mpu Jiwaya, dan terakhir Danghyang Nirartha (Zoetmulder, 1968). Danghyang Nirartha sebagai elite agama pada masa Dalem Waturenggong mereformulasi ide ketuhanan dalam agama Hindu sehingga melahirkan keesaan Tuhan, yakni Tri Purusa melalui padmasana (Atmadja, 2010).

Wrehaspati tattwa disuratkan bahwa Hyang Sada Śiwa berbadan isana, tatpurusa, aghora, bamadewa dan sadyojata. Hal ini mengingatkan pada konsep ajaran Padma Bhuwana atau pengider-ideran di Bali, juga terkait dengan Wijaksara Pancaksara. Kaitanya dalam kekawin Nilacandra dengan sarat sumber yang sama atau penyatuan Siwa ttawa dengan Budhha tattwa, tersirat begitu kental dan lugas ajaran Asta Murti Śiwa yang terdiri dari delapan wujud Śiwa. Asta murti Śiwa juga terkait pada tugas dan fungsi padanda Siwa Budha menjalankan tugasnya memuput suatu upacara. (Asta Murti Śiwa) kedelapan wujud Śiwa itu dibagi menjadi tiga tataran, yakni Bhutamatra, Pranamatra dan Prajñamatra. Dalam tataran paling luar (Bhutamantra) itu berisikian wujud Śiwa dalam lima unsur pembentuk alam semesta (pratiwimurti, jalamurti, agnimurti, wayumurti, akasamurti) tataran yang ditengah (Pranamatra) berisikan wujud Śiwa sebagai Suryamurti dan Candramurti, sementara dalam tataran yang paling atas atau luar (prajnamatra) berisikan wujud Śiwa sebagai yajamanamurti atau Hyang Pasupati.

Ada beberapa kemiripan antara penjelasan Asta Murti Śiwa dengan kemanunggalan Śiwa-Buddha. Hal ini dikarenan dalm proses penyatuan Śiwatatwa dengan Bhudhatattwa, tampak adanya penjelasan tentang Asta Murti Śiwa (Pretiwimurti-yajamanamurti). Begitu pula sebaliknya dalm proses penjelasan Asta Murti Śiwa tentu tidak bisa lepas dari uraian proses penyatuan Śswatatwa dengan Bhudatatwa, karena berasal dari sumber yang sama. Pemujaan terhadap Śiwa sebagai jiwa semesta alam (sira pinaka jiwaning praja) telah banyak tersurat dalam teks Bali Klasik. Diantaranya, dijumpai di dalam kekawin Ramayana (I: 7d), Ketika Sang Dasaratha senantiasa berbakti, menghadap atau memuja Śiwa ( Siwa Bhakti ginong lana Ginawe), Beliaulah yang menjadi ayah dari Dewa Wisnu mejelma (sira ta triwikrama pita, pinaka bapa bhatara wisnu mangjanma). Atau ayah dari sang rama (I:2d). Selanjutnya (I.26cd) ketika Sang Dasaratha melaksanakan yajña untuk memohon keturunan suputra, beliau juga 
memuja Hyang Śiwa (Parameswara inangen-angen, umunggu ring kunda bahnimaya) "Hyang Siwa yang dipikirkan, beliau dihadirkan pada tungku api'.

Sejumlah kutipan diatas menunjukan pemujaan terhadap Śiwa sebagai Dewa pemberi anugrah, walaupun memuat kisah perjalanan seseorang titisan wisnu bernama Sang Rama (I.2c) yang bertujuan menyelamatkan dunia (inakan ikang bhuana kabeh). Cerminan rasa bhakti, pemujaan dan senantiasa menghadap Hyang Śiwa dilakukan, karena dalam ke-Śiwa-an mengajarkan yoga sebagai jalan untuk kembali kepada-Nya, sebagaimana dilakukan oleh Sang Rama, hingga beliau juga disebut Parameswara yang menguasai tiga dunia (jaya parameswara tisaya sakti natha nikanang jagat raya kita), karena sang Rama dianggap telah menunggal dengan Hyang Śiwa, penguasa tiga dunia (Agastia, 2002).

Ajaran ke-Śiwa-an, menempatkan Asta murti Śiwa sebagai hal yang penting dan konsepsi. Sumber-sumber Sanskerta, Jawa Kuna maupun Bali ada menyuratkan dengan suatu uraian yang sangat jelas, terutama berkaitan dengan pelaksanaan yajña dan yajamana. Konsepsi asta murti Śiwa sebenarnya merupakan rumusan ajaran Śiwa tentang kesatuan kosmik dan penciptaan, yang awalnya disuratkan dalam sejumlah kitab purana, seperti matsya purana, lingga purana dan markandya purana. Dalam teks ini, Śiwa disebutkan memiliki delapan wujud dengan delapan nama (asta nama) dan hubungan lima wujud dari Śsiwa yang disebut dengan Pancamukha dan pancabrahma (Agastia, 2002).

Delapan wujud Śiwa (asta murtti Śiwa) terbagi menjadi tiga bagian yang disebut Matra, yang terdiri dari Bhutamatra (Pretiwimurti, Jalamurti, Agnimurti, Wayumurti, Akasamurti), Pranamatra (Suryamuti, Candramurti), dan Prajnamatra (yajamanamurti). Tersusun dari bawah keatas (Pretiwimatra-Yajamanamurti) atau dari luar ke dalam. Yajamanamurti yang disebut sebagai Pasupati atau Śiwa menempati posisi puncak atau paling dalam. Dalam tradisi teks di Bali, konsepsi asta murtti Śiwa di jumpai dalam sejumlah teks maupun puja, sebagaimana tersurat dalam kekawin Ramayana pada sargah XVII, wirama Swagata bait 43) ketika Dewi Sita melontarkan ratapannya kepada Sang Pencipta (Hyang Basundhara Jalgni sateja, Hyang Hangin Gagana Dhaksina Suryya, Hyang Nisakara kita mreta deha, asta murtti kita dewa wisesa). Ratapan rasa sedih Dewi Sita yang mencerminkan konsep asta murti ini dilakukan ketika Dewi Sita dikagetkan oleh Rahwana atas tiruan penggalan kepala Rama dan Laksmana sebagai bukti bahwa suami dan iparnya telah gugur di medan perang. Seirama dengan hal tersebut dalam kekawin Nilacandra juga dijumpai konsep asta murti Siwa, yang diwakili oleh tokoh Yudhistira dan Kresna, keduanya dinyatakan sebagai Hyang Śiwa yang mampu menghancurkan dunia dalam sekejap, karena segala sesuatu yang ada di dunia ini, berkat ciptaan-Nya, hingga sering disebut Hyang Jagat Karana.

\section{a. Prajnamatra (Śiwa/ Pasupati)}

Prajanamatra posisi Hyang Śiwa atau Pasupati menampati paling puncak atau paling dalam. Tidak ada yang tertingi atau terdalam tentang keutamaan-Nya, sungguh disebut sebagai yajamanamurti, sang Maha Pencipta, dan jiwa semesta alam. Jika dalam kekawin Arjuna Wiwaha, disebutkan bahwa panah sakti Siwa pengancur dunia (penglebur jagat) sering diartikan sebagai panah Pasupati, karena panah itu adalah satu-satunya milik Hyang Siwa sebagai Dewa Tertinggi. Anugerah Cadhu Sakti Siwa berupa anak panah (hana penganugrahanku cadhu sakti winimba sara) itu diberikan kepada Arjuna atas ketekunan tapanya demi keberhasilan kakanya Yudhistira dalam memerintah negeri Astina . Kaitnya dengan yajña dan yajamana, dapat dikatakan bahwa asta murti Siwa adalah pandita (Brahmana) yang melaksankan yajña yang disebut dengan yajamana. Sesungguhanya alam semesta ini ialah proses yajña, sementara sang Pandita yang melaksanakan yajña itu adalah sang yajamana atau simbul Śiwa yang disebut Hyang Pasupati.

Pandangan tentang kesatuan semesta inilah yang melahirkan konsep Asta Murti Síwa, dengan menempatkan yajamana, yakni seorang pandita yang sungguh-sungguh yang memahami (prajna) dengan seluk beluk yajña, memami puja serta hakikat pelaksanaan yajña itu sendiri. Hanya dengan menetapkan seorang yajamana yang tepat, pelaksanaan yajña itu 
akan mencapai tujuan, yakni merahayukan dan menyucikan jagat raya ini. Dengan kata lain seorang yajamana terletak pada posisi tertinggi dalam pelaksanaan yajña, yakni prajnamatra (Alit Geria, 2018). Konsepsi asta murti Śiwa terletak pada kekawin Nilacandra, ketika Nilacandra diliputi sifat kemanusiaan, pikiran bingung dan dengan gagahnya mengambil gada sebagai senjata yang menakjubkan lalu bertarung dengan Yudistira di medan laga, ketika pertarungan terjadi, tiba-tiba muncul Hyang Wairocana bersemayam di atas terartai berdaun seribu dengan sejata bajra yang begitu sempurna. Juga hadir Rsi Andhasingha seraya menasihati Nilacandra agar menghentikan peperanganya dengan Yudhistira

Dalam kakawin Nilacandra 2 (VI:35) dijelaskan:

Wastwa hilang ikang jagat matmahan annawa leburen

Kroddha Hyang sri jagat guru ri kita winastwa pwa i sira

Mangdhaydya pwa kita i tip-tipan i kawah pangguha papa

Ping sapta manadi tan anmu muwah sadya karahayon

Terjemahan :

Jika demikian nisacaya dunia akan lenyap menjadi lautan, kemurkaan Hyang Jagat Guru (Śiwa) kepadamu akan menjadi kenyataan ,kamu akan menjadi kerak neraka yang berakhir pada kehinaan walaupun tujuh kali menjelma tidak akan mendapatatkan keselamatan dan kesejahteraan (Alit Geria, 2018).

Dalam kutipan kakawin di atas, adalah cerminan bahwa Śiwa yang menempati posisi Prajnamatra atau tempat tertinggi, karena dinyatakan bahwa ketika Hyang Siwa telah murka maka dunia akan sirna menjadi lautan (Kroddha Hyang Srijagat Guru). Demikan juga yang dilontarkan Rsi Andhasinga terhadap dampak perilaku Nilacandra jika berani durhaka kepada Yudistira sebagai penjelmaan Hyang Jagat Guru (Śiwa). Tentu kutukan yudistira menjadi sebuah kenyataan dan Nilacandra menjadi menderita. Ia akan menjadi keraknya neraka yang berakhir pada kehinaan (kita i ti-tipan i kawah). Karena itulah Nilacandra senantiasa mengabdi pada Yudistra. Dalam kakawin Nilacandra 3 (VIII:9) dinyatakan bahwa jika Nilacandra bisa meraih kemenangan atas anugrah Hyang Wairocana terhadap maharaja Yudistura dan Kresna, maka kehancuran Dunia pun tidak dapat dihindari. Seluruh jagat tiga (bhur, bhwah, swah) akan lembur menjadi samudra lepas (niyata ilang bhuana katrini matemahan dadhya arnawa). Hal ini disebabkan oleh kutukan Hyang Guru (Śiwa) yang sesungguhnya bersemayam dalam diri Nilacandra yang beruwujud Hyang Wairocana, sebagaimana tersurat dakam Kakawin Nilacandra 3 (VIII:9)

Yadi pinjajhan ta sira Kresna kateka-tekaning Yudhistira

Nda kasiddha denta ri rananggana sakari asih Werocana

Niyata ilang bhuana katrini matemahan dadhya arnnwa

Ngka wirodhata bhatara Guru ri kita sanapa kitekana

Terjemahannya:

Seandainya dinda dapat membunuh Sang Kresna dan Sang Yudhistira,

Dan berhasil oleh dinda di Medan perang adalah anugrah Hyang Wairocana.

Tentunya akan hancur dunia ini menjadi lautan yang sangat luas

Saat itu juga akan marah Sang Hyang Guru (Śiwa) dan pasti dinda di kutuk (Alit Geria, 2018).

Demikian kutipan kakawin Nilacandra di atas menekankan ke-adiluhung-an Śiwa sebagai Sang Maha Pencipta yang sering disebut sebagai Sang Hyang Dharma yang menjelma pada diri Yudistira. Selain itu, perihal keutamaan Kresna sebagai penjelmaan Hyang Wisnu juga meduduki posisi penting, karena kedua sosok ini sangat berperan dalam kisah kematian. Nilacandra terdahulu adalah manusia yang utama, berkat belas kasihan Hyang Dharma dan Wisnulah Nilacandra dapat menjelma kembali ke dunia dan menjadi raja di negeri Naraja dan serta disegani oleh rakyatnya. Kedurhakaan Nilacandra kepada yudistira dan Kresna ini cerminan perilaku manusia sombong yang mesti dihukum atas kekeliruan menjalankan Dharma Agama. 


\section{b. Pranamatra (Surya-Candramurtti)}

Delapan wujud Śiwa, surya-candramurti berada pada posisi keenam dan ketujuh dari pranamatra. Kedua wujud Śiwa ini sangat berkaitan dengan sinar atau cahaya suci. Seorang kawi-wiku sangat menyukai istilah surya-candra sebagai pretiwimba untuk kehadiran Sang Pencipta di dalam dirinya. Mpu Kanwa misalnya dalam kekawin Arjuna Wiwaha, menegaskan bahwa bayangan bulan akan tampak jika dalam tempayan berisi air jernih dan suci (sasi wimba haneng gatha mesi banyu, ndan asing suci nirmala mesi wulan) seperti itulah cara menyakinkan Hyang Śiwa di setiap sanubari manusia dengan pikiran suci. Sementara dalam kitab jnana sidhanta, menyembutkan kata surya sebagai perempumaan untuk menjelaskan keyakinan terhadap Sang Maha Kuasa (kadya dyun mesi banu, bhattra kadi surya haneng akasa). Surya- candra, air tempayan yang jernih dan suci adalah kata kunci dalam menyakini adanya Tuhan Yang Maha Kuasa. Dengan demikian, kaitanya dengan asta murti Śiwa, maka Surya-candramurti berada dibawah Yajamana atau Prajnamatra, dan di atas Panca Maha Bhuta dan Bhuta Matra. Disamping sebagai saksi agung jagat raya, Surya-Candra adalah sumber prana, tenaga yang memberi kehidupan atau amerta. Oleh karena itu. Pemujaan Hyang Candra saat purnama dan Hyang Surya (Śiwa Aditya) pada saat Tilem, terlebih saat gerhana bulan dan matahari menjadi penting bagi penganut Śiwa-Buddha.

Kunangiki sang Yudhistira putih kudanya karwe kihen

Kudanira Nilacandra yata karwa warnna krsnamabara

Dinuluri tandha mantri kacatur padha mawa swaliman

Teke ri sipekan kapwa magirang pareng sirabhyagata(Nilacandra 9)

Ndah apari ya lwir ring laku nirang kalih katonye rika

Sawawa sirang Bhatara Śiwa Buddha sang rwa yan ton sira

Dugira Bhatara Gurwa temahan rupih dangu rakweka

Pyawi yawa bhumi mandhala sireng gunungnya maungguh sthiti (Nilacandra 10 )

Terjemahannya :

Adapun (kereta ) sang Yudhistira ditarik oleh dua ekor kuda berwarna putih, Kuda sang

Nilacandra keduanya berwarna biru langit, diiringi keempat mantrinya menunggangi

kuda dan gajah, hingga para prajurit sangat bergembira bersama para tamunya.

Tampak sangat menganggumkan perjalan kedua raja besar itu, bagaikan Bhatara Śiwa

- Buddha kelihatan keduanya, pada waktu itu Bhatara Guru menjelma dahulu disana

konon, juga di bumi jawa yang senantiasa berada di puncak gunung (Alit Geria, 2018).

Kutipan kakawin Nilacandra 1 ( XXIV: 9-10) di atas menyebutkan bahwa kereta Maharaja Yudistira ditarik oleh dua ekor kuda berwarna putih, sementara kereta Maharaja Nilacandra di tarik oleh dua ekor kuda berwana biru langit. Warna kuda putih milik Yudistira menunjukan warna atau cahaya suci yang dipancarkan arah timur oleh Hyang Siwa Aditya (Surya), sedangkan warna kuda biru langit milik Nilacandra mencerminkan warna Kelembutan, kesejukkan sebagai karakter Hyang Candra yang menyinari bumi di malam hari. Sungguh mengagumkan perjalanan kedua maharaja itu, ibarat Hyang Śiwa dan Budhha. Terlebih diingatkan ketika penjelmaan Hyang Guru (Śiwa ) yang senantiasa berada di puncak gunung. Untuk menyebut adanya konsepsi Surya-Candramurti, dilukiskan melalui warna kuda Kresna yang termuat dalam Kakawin Nilacandra 2 (III:12-13) sebagai berikut:

Siwaloka ngaran ira warnna mahireng

Si Bhrapuspa bang ika warnnan i kudha

Ki Sukanta kuning ika warnna wulunya

Ki senya warnnam ika putih trus anulus (nilacandra 12)

Yeka numerakna kareta sang arwa

Pangasih Sanghyang Amarapati ri sira

Pangolyaning jayaphala sanghyang i nguni

Lwir anglayang lari nira sighra gami ya (nilacandra 13)

Terjemahan : 
Si Walaha nama kuda yang berwana hitam, Si Bhrapuspa nama kuda yang berwarna merah. Ki Sukanta yang warna bulunya kuning, Ki Senya yang bulunya berwarna putih bersih

Itulah yang menarik kereta sang raja keduanya anugrah dari Sanghyang Amarapati kepada mereka, itu adalah hadiah keberhasilan dari dewata terdahulu, seperti terbang jalanya hingga segera berada di angkasa (Alit Geria, 2018).

Kutipan kakawin di atas menyebutkan nama dan warna kuda milik Kresna yang diperoleh atas anugrah Hyang Indra terdahulu. Jelasnya bagaikan terbang diangkasa. Berawal dari kuda yang bernama Si Walaha berwarna Hitam menunjukan warna dari Hyang Wisnu, yang menjelma pada diri krisna yang menempati arah utara. Si Bharapuspa yang berwarna merah menunjukan warna dari Hyang Brahma yang beristana di arah selatan. Ki Sukanta adalah nama kuda yang berwana kuning simbol Hyang Mahadewa yang berada di arah Barat. Sedangkan Ki Senya kuda yang berwarna putih merupakan simbul Hyang Iswara, yang menempati arah timur mata angin. Warna putih menunjukan cahaya suci Siwa Aditya sedangkan warna kuning menunjukan cahaya suci yang penuh kelembutan dan keanggungan yang identik dengan karakter Hyang Candra. Ini lah yang akan membentang membentuk sebuah garis horizontal dari arah timur ke barat (Raditya-Buddha / Surya-Candra). Sementara ditengah-tengah membentang garis dari arah utara menuju selatan, hingga membentuk sebuah tapak dara (+). Simbol keseimbangan atau keharmonisan, jika kedua garis (horizontal dan vertikal).

\section{Anunggang ratha kancana manimaya tahun tana siring \\ Warnna swanira sang Yudhistira putih makarwa abagus \\ Kresnambara ta warnna aswanira nilacandra karuwa \\ Kering de nira tandha mantri nira nungganging kuda lima (Nilacandra 7) \\ Mwang peka padha abhyagata lumaku luwir nira ngiring \\ Śiwa-Bhuddha sira luwir bhatara Suryya candra karuwa \\ Saha yan ri catur maharsi lumaku luwir ring akasa \\ Katon de nira sang mulat sakari pinggiring hawanira (Nilacandra 8) \\ Terjemahanya:}

Sama-sama menaiki kereta emas penuh permata tanpak sangat utama tiada yang menyamai. Kuda sang yudhistira berwarna putih dan semuanya bagus, kuda Sang nilacandra keduanya berwarna hitam, diiringi oleh para mentri menaiki kuda dan gajah Seluruh rakyat dan para tamu berjalan kaki di belakang, berwujud Śiwa-Buddha beliau bagaikan Sang Hyang Surya dan Sang Hyang Candra keduanya, didampingi oleh empat maharsi seakan berjalan di angkasa, begitu lah dilihat oleh yang berada di samping kiri dan kanan (Alit Geria, 2018).

Sementara dalam kutipan kakawin Nilacandra 3 (X:7-8) di atas, dinyatakan bahwa kuda Maharaja Yudhistira berwarna putih sebaga simbol sinar atau cahaya suci Hyang Śiwa Aditya (Surya). Sedangkan Kuda Maharaja Nila candra berwarna Hitam kebiruan sebagaimana dalam kekawin Nilacandra I, yang memiliki karakter lembut, agung dan mulia seperti sifat-saifat Hyang Candra. Dalam kekawin Nilacandra 3 ini, perjalannya berdua (yudhistira dan Nilacandra) ke astina sungguh berwujud Śiwa -Buddha yang diibaratkan sebagai Hyang Surya dan Hyang Candra (Śiwa Buddha Sira luwir bhatara Surya Candra karuwa). Kemudian ditegaskan tentang pentingnya pemujaan kepada Hyang Śiwa sebagai saksi agung jagatraya ini, seperti tertera dalam Śiwagama yang berisikan tentang ajaran uatama Ke-Śiwa-an. Terlebih Siwa dijadikan guru oleh para dewata dan para resi kahyangan, hingga disebut Śiwa Guru hal ini terlihat dalam kakawin Nilacandra 3 (XV:5) sebagai berikut

Ndan pwekang Śiwa tatwa mottama Śiwagama karuhunika yadin warah,

Sangkeng Hyang Kirana puja wijilika kaweruhan ta don ya mangkana,

Ndya ta donya bhatara Śiwa ta sinangga ira guru ri dewata kabeh,

Denyan Hyang Śiwa senggahen guru purohita sawatekira rsing langit (Nilacandra 5) 
Terjemahanya :

Perihal ajaran Śiwa sangatlah utama yakni Śiwagama sebagai intinya jika dibicarakan, berawal dari pemujaan kepada Hyang Surya itu mesti diketahui tujuannya, apa yang menyebabkan Hyang Śiwa dijadikan guru oleh para dewata, karena Hyang Siwa dijadikan guru/nabe oleh para rsi di Kahyangan (Alit Geria, 2018)

Pentingnya pemujan terhadap Hyang Surya (Śiwa Aditya) sebagaimana tersurat di atas, menunjukkan pada suatu arah mata angin yakni timur atau kangin yang berarti menuju ke langit (naik) atau matahari terbit (naik) dengan warna putih sumber/inti. Sementara arah barat (kauh) adalah menuju kearah bhuh (bumi) atau matahari tenggelam. Dengan demikian, garis, garis kangin kauh dapat dianalogikan lintas Surya-Candra yang identik dengan Siwa-Buddha. Dalam perspektif budaya dan masyarakat Bali warna putih kuning senantiasa digunakan terutama yang berkaitan dengan hal-hal kesucian atau niskala (kamoksan) (Alit Geria, 2018).

\section{c. Bhutamatra (pertiwi-Akasamurti)}

Teks kekawin Nilacandara disebutkan adanya penunggalan dua hal yang bersisian (Śiwa-Buddha) kembali kewujud penunggalan semula yakni Bhatara Guru. Upacara ini seyogyanya dilakukan disebuah tempat yang secara simbolis dianggap sebagai madhyaning bhuana (tengah dunia) disebut natah/lebuh dan catuspatha/pempatan dimana pretiwi (bhumi/tanah) dan akasa (langit ) bertemu. Dilakukannya upacara bhuta yadnya ini, pada hakikatnya memuja Hyang Śiwa (Pasupati)melalui proses somya atau penyucian alam semesta. Kaitanya dengan Asta Murti Siwa, dapat dikatakan bahwa akasamurti terletak pada urutan tertinggi pada tataran Bhutamatra (pratiwimurti-akasamurti). Demikian proses dikisakan terciptanya dunia oleh Hyang Maha Kuasa yang dibentuk oleh unsur Panca Maha Bhuta dan Panca Tan Matra, sebagai wujud, asta murti Śiwa yang menduduki posisi Bhuta Matra (Pretiwi Murti, Jalamurti, Agnimurti, Wayumurti, Akasamurti) Disini juga tercermin bahwa ketika Hyang Śiwa Guru bersisian wujudnya sebagai Śiwa-Buddha, Ia diyakini mengandung unsur Purusa-Pradhana ini bertemu, maka akan terjadi penciptaan baru.

Patunggalan ika Śiwa-Buddha pan padha sinanggraha lima wisaya

Mwang panca bhuta lawan i panca Tanmantra witani bhuana kabeh,

Ndhya kalingan ika ni hana linga kita rika pratama nika nguni

Duknya hana kami irikang pretiwi maya tatwa bhasawa ya kami

(nilacandra 11)

Iswara kami yana ri Śiwatatwa Mugasiddhi ya ri Tatagata

Wisnu pasarira kami ring twakindrya ganalalita hana ni kami

Hanangku ri bhuawana sarira wus hana pamutyanaku sariramu

Um kita laki si Nilacandra yan ring apa hanangku wuwusana kita

(nilacandra 12)

Hyang Maha Narayana ri Śiwatatwa Mitabha yana ri tatagata

Yaning dhaging ika linga ring rasa ya kahanangku yana ri sarira

Wisnwaku guna nira sikayana hana ri teja tucapana kabeh

Wisnu jati yan ana ri Śiwatattwa muwah aksabiya ri sugata (nilancandra 13)

Sarwwa sahana-hanani wastu akwa yan ana ngkana surupa riya,

Yan ring bhayu wuwusa Brahma yan i Siwatatwa tatan ana waneh

Ratnasabhawa yata ri Bhudapaksa ri sparsa aku ya ikana

Yan ring akasa amara rudra aku Śiwatatwa masarira kana (Nilacandra 14)

Terjemahanya

Penyatuan Śiwa-Bhudda itu berjalan karena sama sama mengandung lima unsur, demikian pula panca maha hhuta dengan panca tan matra yang menjiwai dunia seluruhnya, karena hal itu adalah unsur dirimu pada awalnya terdahulu, ketika aku sedang berada di buii dan saat itu Mayatatwa yang menjiwai diriku. 
Sang Hyang Iswara pada siwa tatwa (filsafah Śiwa ) sama dengan Amoghasidhi itu pada Tataghata, Wisnu bersemayam padaku itu letaknya pada twakindriya dengan leluasa namun sangat lues ada bersemayam padaku, keberadaan diriku menjiwai dunia juga telah ada pada jiwamu, wahai Nilacandra dimanapun keberadaan dirimu juga ada disana.

Hyang Wisnu pada Śiwatatwa dan Amitabha pada Tatagata, bila bersemayan pada daging yang punya rasa maka keberadaan ku pada badan kasar, aku yang berupa Wisnu itu ada pada guna yang berupa teja (sinar) bersemayam di setiap ucapan. Wisnu yang maha besar pada Siwatatwa dan Aksabhya pada Sogata.

Segala yang ada di setiap waktu akhirnya akan menyatu adanya, apabila pada bayu (angin ) tersebut Brahma dikatakan pada Śiwatattwa tiada lain, disebut ratnasambhawa, pada ajaran Buddhaitu atau sparsa tiada lain. Kalau di angakasa Sang Hyang Rudra pada Śiwattwa bersemayam (Alit Geria, 2018).

Kutipan kakawin di atas menunjukan kisah penyatuan Śiwa-Budhha yang sama-sama mengandung lima unsur dalam alam (Panca Maha Bhuta, Panca Tan Mantra) sebagai jiwa dunia seluruhnya. Berawal dengan keberadaan-Nya di bumi yang dijiwai oleh Mayatattwa. Ia disebut Hyang Iswara pada Śiwattwa (Filsafah Śiwa) dan disebut Amoghasidhi pada Tataghata. Saat itu Hyang Wisnu bersemayam pada-Nya, terletak pada Twakindriya bersifat sangat halus yang menjiwai dunia. Termasuk yang bersemayam pada diri Nilacandra. Disebut Wisnu pada Siwattawa dan amitabha pada Tataghata, ia bersemayam pada daging yang punya rasa dan berada pada badan kasar. Ia dalam wujud wisnu itu berada pada guna berupa teja (sinar) bersemayam di setiap ucapan. Karena itu, Wisnu yang maha besar pada Siwatattwa juga disebut aksabyah pada Sogata dan segala yang ada di setiap waktu akhirnya menyatu. Kemudian ketika berada pada bayu (angin) ia disebut Brahma pada Śiwatattwa, dan disebut denan Ratna Sambhawa pada ajaran Buddha, yang terletak pada sparsa (sinar) tiada lain. Kalau di akasa ia berwujud Hyang Rudra pada Śiwatattwa, dan Hyang Wairocana pada ajaran ke-buddha-an. Itulah sesungguhnya wujud Wisnu, yang senantiasa menciptakan kesuburan dunia demi kelangsungan mahluk hidup.

\section{Faktor Filosofis}

Atas dasar cinta atau berkawan pada ilmu, kepandaian pengetahuan atau kebijaksanaan inilah para ahli terus menerus mencari fakta-fakta dan hakekat kebenaran sejati terhadap sesuatu hal atau keadaan sesuai dengan bakat dan keperluannya. Secara etimologi seperti di atas itu, banyaklah adanya definisi-definisi filsafat yang dikemukakan oleh para filosof, menurut tanggapan atau hypotesa dan sistem penelitian serta penganalisaannya masing-masing. Dari proses penelitian akal pikiran yang logis, bermetodos dan sistematis timbullah pengertian, dengan adanya pengertian ini selanjutnya akan menimbulkan pengetahuan dan dari pengetahuan yang sempurna kemudian akan menumbuhkan kebijaksanaan atau pengetahuan yang sempurna itulah yang disebut kebijaksanaan. Apabila kebijaksanaan ini telah diamalkan lahir bathin dalam berbagai-bagai bentuk kegiatan dan juga jika telah adanya persesuaian antara kebijaksanaan itu dengan obyeknya, maka itulah disebut kebenaran menurut hipotesa filsafat. Jadi secara singkatnya dapat dinyatakan bahwa kebenaran dalam filsafat itu adalah hasil persesuaian lahir bathin antara kebijaksanaan dengan obyeknya yang identik dan harmonis.

Adapun macam serta tingkat dan nilai dari pada kebijaksanaan atau kebenaran tersebut berbeda-beda, tergantung pada perkembangan situasi dan kondisi (desa, kala, patra) serta menurut dasar dan tujuan penyelidikannya, sesuai dengan kemampuan logika manusia yang berfilsafat. Maka itu banyaklah terdapat pandangan atau pengertian tentang kebenaran atau kebijaksanaan tersebut. Seperti halnya pada jaman Sokrates, yang dimaksud dengan kebijaksanaan atau kebenaran ialah segala aspek budi pekerti yang baik, karena dalam hal ini Sokrates lebih mementingkan unsur etika dalam berbagai aktivitas perilaku manusia (Poedjawijatna, 1978). Demikian juga pada jamannya Plato, adapun yang dimaksudkan 
kebenaran atau kebijaksanaan itu, ialah orang yang telah mempunyai ide kebaikan. Karena manusia ini menurut Plato hidup dalam dunia dua yaitu dunia idea dan dunia pengalaman. Idea ini bersifat tetap dan realitas, sedangkan pengalaman itu sifatnya berubah-ubah dan semu. Oleh karena itu, bahwa barang siapa yang mempunyai idea kebaikan, dialah yang disebut orang yang bijaksana atau orang yang telah mencapai kebenaran (Bertens, 1981).

Bagi pengikut aliran Stoa pada jaman Hellenisme di Eropa, mengganggap bahwa kebijaksanaan atau kebenaran itu ialah keharmonisan hidup, manusia dengan alam, karena manusia ini adalah bagian dari pada alam itu sendiri. Dan menurut paham Stoa bahwa alam ini sebenarnya tidak berbeda dengan Tuhan atau Tuhan itu adalah alam dan alam itupun adalah Tuhan (Poedjawijatna, 1978). Akan tetapi berbeda dengan pandangan rohani bagi orang agamawan, bahwa yang dianggapnya kebenaran yang hakiki dan tertinggi adalah Tuhannya sendiri dan apabila seseorang telah dapat memperasatukan roh atau jiwanya dengan Tuhan, itulah sesungguhnya orang bijaksana yang telah dapat mencapai kebenaran dan kebahagiaan yang abadi, hal ini disebut "moksa" menurut paham Hinduisme.

Moksa dalam agama Hindu merupakan tujuan akhir yang ingin dicapai dalam keyakinan agama Hindu, yang merupakan kelepasan dari lingkaran kelahiran. Alam kelepasan dalam keyakinan agama Hindu akan menuju alam Śūnya dan Nirwana dalam keyakinan agama Buddha. Śunya dalam keyakinan ajaran agama Hindu merupakan keadaan setelah pikiran bebas dari dirinya sebagai yang berpikir dan sekaligus yang dipikirkan. Luput dari angan-angan bila diceritakan, bagaikan inti angkasa yang sunyi yang merupakan kesadaran yang tertinggi (paramaśiwa). Kesadaran śūnya antara lain bercirikan suci, murni, tiada, bahagia, nirmala, bebas, tak terbatas, sempurna, lebur luluh dalam pemujaannya pada pengalaman keindahan sejati, śūnya itulah paramaśiwa, paramaśiwa itulah śūnya (Palguna, 2014).

Keadaan śünya sering diidentikan dengan nirwana (nirbāna) dalam agama Buddha. Nirwana (nirbāna) merupakan pembebasan dari sengsara yang terakhir dengan penyatuan kembali dengan sang pencipta. Ajaran ini adalah tujuan akhir dari ajaran agama Buddha. Bila dicermati antara nirwana (nirbāna) (tanpa tiupan) dan śünya (sunyi, sepi) pada prinsipnya memiliki tujuan yang sama yaitu pencapaian tujuan akhir dari ajaran agama Hindu dan Buddha untuk mencapai sukha tan pawali dukha (kebahagiaan yang tidak diikuti oleh penderitaan). Dalam keyakinan agama Hindu dan Buddha apabila telah mencapai nirwana (nirbāna) dan śūnya orang akan tidak mengalami reingkarnasi lagi.

Secara filosofis keharmonisan Śiwa-Buddha di Bali dalam konsep ajaran kelepasan dalam keyakinan agama Hindu akan menuju alam Śünya dan Nirwana dalam keyakinan agama Buddha. Keadaan śūnya sering diidentikan dengan nirwana (nirbāna) dalam agama Buddha. Nirwana (nirbāna) merupakan pembebasan dari sengsara yang terakhir dengan penyatuan kembali dengan sang pencipta (Putra, 2020). Bila dicermati antara nirwana (nirbāna) (tanpa tiupan) dan śúnya (sunyi, sepi) pada prinsipnya memiliki tujuan yang sama yaitu pencapaian tujuan akhir dari ajaran agama Hindu dan Buddha untuk mencapai sukha tan pawali dukha (kebahagiaan yang tidak diikuti oleh penderitaan). Nirwana (nirbāna) merupakan pembebasan dari sengsara yang terakhir dengan penyatuan kembali dengan sang pencipta. Ajaran ini adalah tujuan akhir dari ajaran agama Buddha. Dalam keyakinan agama Hindu dan Buddha apabila telah mencapai nirwana (nirbāna) dan śünya orang akan tidak mengalami reingkarnasi lagi.

\section{Faktor Historis}

Ajaran Śiwa dan Buddha berkembang pada era Majapahit sekitar abad ke-14 di Jawa Timur berdasarkan bukti penunggalan kakawin Arjuna Wijaya dan Sutasoma dapat dijadikan bukti adanya penunggalan tersebut (Slamet, 2012). Penyebaran kedua agama ini tersebar diberbagai pelosok dan terus berlanjut akibat adanya kesamaan dalam beberapa hal, khususnya di dalam memandang hakikat yang Tunggal. Perkembangan yang sangat pesat kedua agama ini dengan pendekatan Tantrayana sebagai media penghubung terjadinya penunggalan agama Mahayana dan Śiwa mendorong terjadinya penunggalan itu. Latar belakang inilah, maka ajaran 
Śiwa-Buddha yang berkembang pada era Majapahit di Jawa Timur dapat dikatakan sebagai agama "Śiwa-Buddha Tantris", dengan melihat begitu kuatnya ajaran-ajaran Tantrayana, khususnya Wajrayana ke dalam kedua agama ini. Sebagaimana diketahui sebelumnya bahwa ajaran Tantrayana mempunyai orientasi kosmologis dan kosmogonis dimana Bhuana Alit (mikrokosmos) merupakan bagian tak terpisahkan dari Bhuana Agung (makrokosmos); mikrokosmos adalah miniatur makrokosmos karena adanya kesamaan dalam hakikat.

Secara historis walaupan di daerah asalnya Śiwa-Buddha mengalami pertentangan yang sangat hebat dan menjadi catatan sejarah yang kelam, akan tetapi di Indonesia malah sebaliknya Siwa-Buddha hidup rukun dan hamonis. Menurut dugaan dari I Gusti Bagus Sugriwa, mungkin semenjak Sri Airlangga memerintah di Jawa paham Śiwa Buddha ini kian erat dipersatukan sampai juga ke Bali, karena masa itu yang memegang ialah adiknya sendiri. Pernah juga Sri Airlangga mengutus dua orang guru agama yaitu Mpu Kuturan dan Mpu Bharadah, pergi ke Bali untuk mengajarkan agama Siwa Buddha. Kemudian pada jaman SriJayapangus memegang tapuk pemerintahan di Bali, pada prasasti Saka 1103 ada terdapat sebutan Mpungku ŚiwaSogata-Rsi Mahabrahmana, terutama Rsi Gatanyu dan Rsi Taruna penganut Śiwa-Wesnawa. Dari jaman itu tampak ada Tri Sadhakayaitu Buddha Mahayana, Śiwa dan Wesnawa. Akhirnya Rsi Wesnawa itu disebut Sangguru (Sengguhu). Tetapi warnanya tetap dua, yaitu Śiwa dan Buddha (Sugriwa, 2008).

\section{Faktor Psikologis}

Tantra nampaknya mempengaruhi sebagian besar prilaku kehidupan sekte-sekte di Bali. Agama nenek moyang atau agama "asali" (pra-Hindu) di Bali adalah agama yang sangat erat sekali hubungannya dengan mistis dan magis. Agama Śiwa dan Buddha memiliki karakter yang mirip dengan agama nenek moyang di Bali, sehingga apabila membahas tentang tantris, maka akan berhubungan dengan magis dan mistis. Tantra adalah tradisi kompleks yang terjalin dalam spiritualitas Hindu, berhubungan dengan kebenaran tertinggi sebagaimana disebutkan dalam Kitab-kitab Sruti (Veda) dan cara-cara rahasia untuk merealisasinya. Konsep tantra Hindu menjelaskan bagaiaman Ida Hyang Widhi meciptakan alam, dimana Purusa dan Prakerti adalah Siwa dan Saktiya, bersatunya atau bertemunya Siwa dan Saktinya adalah proses mencipta (Jelantik oka, 2009:215). Itu merupakan wujud (manifestasi) abadi penyatuan antara Siwa dan Saktinya, sebagai" pernainan" disebut dengan lila menari nari dalam ciptaanNya. Tarian Siwa ini lah yang disebut Siwa Nataraja. Dalam wujud releksi manifestasi Siwa nata raja tidak ada yang kekal, dan selalu berubah setiap saat, dalam falsafah buddha disebut Pratita samudbawa (tidak ada yang kekal). Konsep Tantra Buddha lebih menitik beratkan hubungan bathin dengan semuanya, dengan kata lain kesamaan Bhuana Agung (alam) dengan Bhuawa Alit (manusia) yaitu: Pikiran dengan alam semesta, Dunia spritual dengan dunia benda, Upacara dengan kenyataan.

Tujuan keseimbangan Bhuwana Agung dan Bhuwana Alit dapat dicapai apabila dalam pelaksanaannya perlu cara-cara tertentu sebagai elemen-elemen utama yaitu Yantra (yang terlihat ) simbo-simbol yang disusun secara terartur, Mantra (yang terdengar) untaian kata yang keramat dan Mudra (yang dapat dirasakan) berbagai sikap tangan yang menyertai Mantra dan Yantra (Jelantik Oka, 2009). Eksistensi ajaran Śiwa-Buddha di Bali sebagai akibat adanya kontak langsung antara pengaruh kebudayaan India dan Nusantara khususnya Bali. Sejak itu pengaruh India semakin terasa Bali yang ditandai dengan berdirinya kerajaan-kerajaan yang memeluk agama Hindu dan Buddha terutama di Jawa dan Kalimantan. Peninggalanpeninggalan berupa benda-benda arkeologi maupun teks kesusastraan berbahasa Jawa kuno dan Lontar-lontar di Bali menunjukkan adanya pengaruh tersebut.

Ajaran Śiwa-Buddha yang Tantris, tubuh manusia sebagai miniatur alam semesta menjadi pusat pencarian menuju yang Tunggal melalui penggunaan Aksara, Mantra, Yantra, Mudra, dan Yoga. Tubuh manusia dijadikan sarana sekaligus Sadhana untuk mencapai penunggalan. Maka dari itu laboratorium terbesar yang ada di muka bumi ini adalah tubuh 
manusia yang menurut filsafat Sangkhya berasal dari Prakrti (unsur kebendaan) yang dibangun oleh tiga konstituen dasar, yaitu Satwam, Rajas dan Tamas atau disebut psikologi Hindu. Tubuh manusia hingga bentuknya seperti sekarang ini mengalami evolusi kosmos, moral secara bertahap dari yang paling halus (suksma) hingga menjadi yang paling kasar (sthula) yang terdiri atas Panca Maha Bhuta (pertivi, apah, teja, vayu, dan akasa). Praktek "Panca Makara" atau "Panca Tattwa": Mada, Matsya, Mudra, dan Maithuna mewarnai praktek agama Śiwa-Buddha ini. Praktek agama Śiwa-Buddha sangat kental dengan unsur-unsur di atas sehingga nampak berbeda dari sumber awalnya, yaitu Weda maupun dari ajaran Śiwa atau Buddha awal.

Secara psikologis konsep tantra yang meliputi elemen-elemen mantra, yantra dan mudra inilah yang menjadi salah satu penyebab harmonisasi antara Śiwa dan Buddha di Bali, oleh karena bila dicermati bahwa tujuan tertinggi tantra Hindu dan Buddha adalah "keadaan sempurna". Eksistensi ajaran Śiwa-Buddha di Bali sebagai akibat adanya kontak langsung antara pengaruh kebudayaan India dan Nusantara khususnya Bali. Sejak itu pengaruh India semakin terasa Bali yang ditandai dengan berdirinya kerajaan-kerajaan yang memeluk agama Hindu dan Buddha terutama di Jawa dan Kalimantan. Peninggalan-peninggalan berupa bendabenda arkeologi maupun teks kesusastraan berbahasa Jawa kuno dan Lontar-lontar di Bali menunjukkan adanya pengaruh tersebut.

Ajaran Śiwa-Buddha yang Tantris, tubuh manusia sebagai miniatur alam semesta menjadi pusat pencarian menuju yang Tunggal melalui penggunaan Aksara, Mantra, Yantra, Mudra, dan Yoga. Tubuh manusia dijadikan sarana sekaligus Sadhana untuk mencapai penunggalan. Maka dari itu laboratorium terbesar yang ada di muka bumi ini adalah tubuh manusia yang menurut filsafat Sangkhya berasal dari Prakrti (unsur kebendaan) yang dibangun oleh tiga konstituen dasar, yaitu Satwam, Rajas dan Tamas atau disebut psikologi Hindu. Tubuh manusia hingga bentuknya seperti sekarang ini mengalami evolusi kosmos, moral secara bertahap dari yang paling halus (suksma) hingga menjadi yang paling kasar (sthula) yang terdiri atas Panca Maha Bhuta (pertivi, apah, teja, vayu, dan akasa). Praktek "Panca Makara" atau "Panca Tattwa": Mada, Matsya, Mudra, dan Maithuna mewarnai praktek agama Śiwa-Buddha ini. Praktek agama Śiwa-Buddha sangat kental dengan unsur-unsur di atas sehingga nampak berbeda dari sumber awalnya, yaitu Weda maupun dari ajaran Śiwa atau Buddha awal.

Secara psikologis ajaran Śiwa-Buddha yang tantris, tubuh manusia sebagai miniatur alam semesta menjadi pusat pencarian menuju yang Tunggal melalui penggunaan Aksara, Mantra, Yantra, Mudra, dan Yoga. Śiwa-Buddha adalah sebuah konsep kesatuan antara dua paham kepercayaan yang berbeda, yang lebur menjadi satu saling melengkapi satu penunggalan ke dalam bentuk Padma Mani dan selanjutnya divisualkan dalam bentuk Padmasana berkembang di Bali. Bhatara Śiwa dan Bhatara Buddha dikatakan bersthana di atas Padmasana, Śiwa-Buddha dikatakan sebagai Parwatarajadewa yaitu bukan Śiwa dan bukan pula Buddha, melainkan Śiwa-Buddha sebagai prinsip tertinggi, raja dari semua dewa (Titib, 2003). Konsep ini menjadi konsep pemersatu dari perbedaan-perbedaan di antara kedua agama ini yaitu Śiwa dan Buddha. Secara psikologis konsep tantra yang mantra, yantra dan mudra inilah sebagai penyebab harmonisasi antara Śiwa dan Buddha di Bali, oleh karena bila dicermati bahwa tujuan tertinggi tantra Hindu dan Buddha adalah "keadaan sempurna".

\section{Faktor Sosiologis}

Śiwa dan Buddha dapat hidup rukun di tanah Jawa dan terbawa kerukunan tersebut sampai ke Bali. Bersatunya Śiwa-Buddha di Bali tejadi tidak lepas dari ikatan kewangsaan, hal ini dimulai dari Mpu Baradah atau Mpu Pradah yang memiliki dua orang putra yaitu: Mpu Shiwagandu dan Mpu Bahula Candra. Baik Shiwagandu ataupun Bahula sama sama memilki arti yang utama. Dari Mpu Bahula lahirlah Mpu Tantular, yang terkenal sebagai seorang pengawi hebat. Beliaulah yang menciptakan kakawin Sutasoma, Kakawin Arjuna Wijaya, dan Kunjara Karma Dharma Kanthana. Mpu Tantular juga bergelar Mpu Angsokanatha, ada empat putra dari Mpu Tantular : Dang Hyang Panawasika (sulung), Mpu Siddhimantra atau Mpu 
Bekung, Mpu Dang Hyang Smaranatha, Dang Hyang Kapakisan (Bungsu ). Selanjutnya Dang Hyang Panawasika melahirkan Dang Hyang Angsoka dan dari Dang Hyang Angsoka inilah melahirkan Dang Hyang Astapaka yang menjadi cikal bakal adanya warga Brahmana Buddha di Bali. Disisi lain Dang Hyang Semaranatha melahirkan Dang Hyang Nirartha yang menurunkan warga Brahmana Siwa di Bali (Palguna, 2015).

Kedatangan Dang Hyang Nirartha ke Bali yang merupakan cucu dari Mpu Tantular yang tinggal di Jawa timur (Majapahit), semasih muda beliau adalah pemeluk ajaran Buddha, kemudian menikah dengan Diah Komala atau bernama Dewi Komala yang setelah sebagai pendeta bernama Ida Padanda Istri Mas, putri dari Dang Hyang Panataran dari Geria Mas Kemenuh Daha Mas Jawa timur yang memeluk Agama Siwa. Setelah melakukan upacara pernikahan, Dang Hyang Nirartha memeluk agama Siwa dan tinggal di Daha atas permintaan mertuanya dan dinobatkan sebagai Pendeta. Dang Hyang Niratha, ketika menjadi Purohita atau Bagawanta Raja Bali Ida Dalem Waturenggong, dengan agem-ageman gegelaran yaitu Śiwa. Pada saat itu Ida Dalem Waturenggong akan mengadakan upacara Homa Yajña yang bertujuan untuk kerahyuan jagat. Dalem Waturenggong berkenan mengundang Pendeta Buddha Dang Hyang Angsoka untuk untuk mendampingin Dang Hyang Nirartha memimpin pelaksanaan Homa Yajña. Oleh karena Dang Hyang Angsoka tidak berkenan meninggalkan Majapahit, dan kemudian beliau mengutus anaknya datang ke Bali yang bernama Mpu Katrangan. Sebelum diutus ke Bali digodok lagi beliau belajar ajaran "budaya delapan kebenaran", astapaka dengan ajarannya astanidya, sehingga beliau terkenal namanya dengan Astapaka. Pada akhirnya beliau pergi ke Bali untuk memenuhi undangan Ida Dalem Waturenggong. Jadi, dapat dipahami bahwa Dang Hyang Nirartha dan Dang Hyang Astapaka merupakan simbol dimensi toleransi dalam kehidupan keberagamaan.

Kaidah dasar kehidupan masyarakat Jawa adalah prinsip kerukunan,dan orang Jawa akan berusaha untuk memperlakukan orang lain seperti anggota keluarga. Bertitik tolak dari budaya Jawa asli yang pada prinsipnya untuk menjaga keselarasan sosial dan selalu mengupayakan keharmonisan dalam kehidupan, Śiwa dan Buddha dapat hidup rukun di tanah Jawa dan terbawa kerukunan tersebut sampai ke Bali. Selain dari Budaya Jawa asli, bersatunya Śiwa-Buddha di Bali tejadi tidak lepas dari ikatan kekeluargaan atau kewangsaan. Secara sosiologis, masyarakat Hindu Bali mengakrabi bahwa Śiwa dan Buddha itu memang satu dan Esa. Bhatara Śiwa-Buddha dengan sifat-sifat Ardhanareswari di Bali di kenal sebagai Hyang Tunggal (Redana et al., 2019). Berkat dari usaha dan penyelarasan konsep kehidupan dari rohaniawan tersebut, kehidupan sosial masyarakat mulai membaik yang salah satunya dengan diciptakannya konsep kahyangan tiga dan tri sadhaka. Konsep inilah yang nampaknya merawat sosio-religius masyarakat Bali (Sukrawati, 2019).

\section{Kesimpulan}

Siwa-Budha hidup berdampingan dan harmonis di Bali, hal ini ditandai dengan terdapatnya Pandita Siwa dan Pandita Budha dalam memimpin upacara keagamaan di Bali yang terdapat di Pura Besakih. Keharmonisan tersebut dilatar belakangi oleh beberapa faktor yaitu faktor teologi, filosofis, historis, psikologis dan sosiologis. Faktor teologi, keesaan ŚiwaBuddha disebut dengan Sanghyang Tunggal. Faktor filosofis, alam kelepasan dalam keyakinan agama Hindu akan menuju alam Śūnya dan Nirwana dalam keyakinan agama Buddha. Śūnya dalam keyakinan ajaran agama Hindu merupakan keadaan setelah pikiran bebas dari dirinya sebagai yang berpikir dan sekaligus yang dipikirkan. Faktor historis, secara singkat dapat dijelaskan bahwa Ajaran Śiwa dan Buddha berkembang pada era Majapahit sekitar abad ke-14 di Jawa Timur. Faktor psikologis Secara psikologis ajaran Śiwa-Buddha yang tantris, tubuh manusia sebagai miniatur alam semesta menjadi pusat pencarian menuju yang Tunggal melalui penggunaan Aksara, Mantra, Yantra, Mudra, dan Yoga. Dan faktor sosiologis, masyarakat Hindu Bali mengakrabi bahwa Śiwa dan Buddha itu memang satu dan Esa. Bhatara ŚiwaBuddha dengan sifat-sifat Ardhanareswari di Bali di kenal sebagai Hyang Tunggal 


\section{Daftar Pustaka}

Agastia, I. B. G. (2002). Padmasana dan Síwa-Buddha Puja. Yayasan Dharma Sastra.

Alit Geria, A. A. G. (2018). Wacana Siwa-Buddha Dalam Kekawin Nilacandra. Cakra Media Utama.

Atmadja, N. B. (2010). Bali pada Era Globalisasi Pulau Seribu Pura Tidak Seindah Penampilannya. LkiS.

Bertens, K. (1981). Ringkasan Sejarah Filsafat, Penerbit. Yayasan Kanisius.

Girinata, I. M. (2020). Interpretasi Terhadap Sloka 40 Kitab Sarasamuscaya Tentang Visi Misi Pandita Masa Depan. Sphatika: Jurnal Teologi, 10(2). https://doi.org/10.25078/sp.v10i2.1585

Goris, R. (1974). Sekte-sekte di Bali. Bhratara.

Goris, R. (1984). The Religious Character of the Village Community, dalam Bali Studies in Life, Thought, and Ritual. Foris Publication.

Jelantik Oka, I. P. G. N. (2009). Sanatana Hindu Dharma. Widya Dharma Denpasar.

Kiriana, I. N. (2021). Hibriditas Śiwa dan Buddha dalam Upacara tawur Kasanga di Bancingah Agung Pura Besakih.

Mantra, I.B., D. (2002). Siwa-Buddha Puja di Indonesia. Yayasan Dharma Sastra.

Palguna, D. I. (2014). Dharma Śūnya. Sadampaty Aksara.

Palguna, D. I. (2015). Shastra Wangsa (Kamus Istitah Wangsa Bali Pustaka, Pusaka Manusia). Sadampaty Aksara.

Poedjawijatna, I. . (1978). Pembimbing ke arah Alam Filsafat. PT. Pembangunan.

Putra, I. G. A. D., \& Indrayani, A. A. D. (2020). SIWA TATTWA PURANA [RITUALRITUAL KEHIDUPAN DAN KEMATIAN]. Kalangwan Jurnal Pendidikan Agama, Bahasa Dan Sastra, 10(1). https://doi.org/10.25078/klgw.v10i1.1387

Redana, M., Wirawan, A. A. B., Parimartha, I. G., \& Anom Kumbara, A. A. N. (2019). RECONSTRUCTION OF HINDU PRIEST IN THE DYNAMICS OF THE INTER TRI SADHAKA AND SARWA SADHAKA IN BALI. E-Journal of Cultural Studies. https://doi.org/10.24843/cs.2019.v12.i02.p01

Slamet, M. (2012). Menuju Puncak Kemegahan: Kerajaan Majapahit. Printing Cemerlang.

Sugriwa, I. (2008). Siwa-Buddha Bhinneka Tunggal Ika. Yayasan Dharma Sastra.

Suhardana, K. (2008). Dasar-dasar Kesulinggihan. Paramita Surabaya.

Sukrawati, N. M. (2019). EKSISTENSI DAN PERANAN PANDITA BALI AGA DALAM PENDIDIKAN KEAGAMAAN UMAT HINDU DI KOTA DENPASAR. Dharmasmrti: Jurnal Ilmu Agama Dan Kebudayaan, 19(1). https://doi.org/10.32795/ds.v10i1.338

Titib, I. M. (2003). Teologi \& Simbol-Simbol dalam Agama Hindu. Paramita.

Zoetmulder, P. . (1968). Old Javanese-English Dictionary. segravenhage Martinus Nijhoff. 